Article

\title{
Water Availability Coincides with Population Declines for an Endangered Butterfly
}

\author{
Heather L. Cayton * and Nick M. Haddad \\ W. K. Kellogg Biological Station, Department of Integrative Biology, Michigan State University, Hickory Corners, \\ MI 49060, USA; nick.m.haddad@gmail.com \\ * Correspondence: heather.l.cayton@gmail.com; Tel.: +1-269-671-5117
}

Received: 12 June 2018; Accepted: 16 August 2018; Published: 20 August 2018

check for updates

\begin{abstract}
As global climate change causes population declines across numerous taxa, it becomes critical to understand the specific pathway by which climatic and anthropogenic factors influence population size. Water availability is a key environmental condition that links climate and humans to species response, especially for rare or threatened butterflies that are highly sensitive to changes in climate and the surrounding landscape. We use the wetland-dependent endangered St. Francis' satyr butterfly (Neonympha mitchellii francisci) to test how changes in water availability affect population size via changes in host plant growth. We show that long-term declines in water availability are directly linked to a decline in host plant growth and contributed to a population decrease of $95 \%$ for St. Francis' satyrs in the past decade, threatening the persistence of the species. Recent restoration work, which includes efforts to increase water availability via hardwood removal, has been successful in increasing population numbers. Many butterflies are broadly dependent on water availability and flow, and only by understanding the specific pathway that directly links water availability to species response can we make effective conservation plans to prepare for the altered water conditions of the future.
\end{abstract}

Keywords: Neonympha mitchellii francisci; population decline; precipitation; St. Francis' satyr; butterfly; temperature; water flow; restoration

\section{Introduction}

Global climate change has contributed to population declines across numerous taxa [1-4]. These declines are exacerbated by human modification of the landscape [5], particularly when that modification alters or removes critical natural resources from the environment and limits options for adaptation [6]. Although some mechanisms by which climate and humans interact to influence ecosystem processes and species interactions have been identified $[7,8]$, the pathway that leads to quantifiable declines in population numbers remains unclear $[3,9]$. This is especially true for changes to precipitation and water availability that can have the most extreme effects on populations of rare species, as we show here.

Greater human pressure on the landscape magnifies climate conditions by exacerbating natural resource scarcity, predominantly water availability $[10,11]$. Changes in precipitation patterns directly impact both water availability and flow, which would have a large impact not only on wetland and riparian species, but on many species generally sensitive to topography and microclimate around water sources $[12,13]$. These effects could be exacerbated by increases in the local human population and land use, for example via increased water consumption or greater fragmentation of riparian ecosystems $[14,15]$.

Changes in water availability can directly impact population size in multiple ways. For example, plants that depend on natural stream flow regimes for seed dispersal may suffer from reduced rates 
of recruitment under less predictable conditions [16]. The pathway linking primary producers to consumers may be interrupted by changes in water availability, resulting in a cascading effect across multiple species $[17,18]$. Precipitation can have an added indirect effect on individuals in very simple ways, such as limiting growth via too little rainfall or over-inundating minimally wet landscapes via too much rainfall. Both direct and indirect links can fundamentally change the size of populations, and therefore the likelihood of long-term population persistence.

Butterflies in particular are sensitive to conditions that alter normal patterns of temperature [19] or precipitation [20], and there is evidence that lepidopteran populations around the globe have declined as a direct result of climatic factors [21-23]. Rare and endangered butterflies, whose narrow distributions make them more vulnerable to extinction under climate change [24-26], represent a critical case for understanding how climate, humans, and population size are linked. For these species, water availability may be the key environmental condition determining population persistence. For example, in floodplain areas, changes in water inundation can have negative impacts on egg survival [27] or larval survival [28,29], or impact local species composition [30]. Reduced water availability may also impact butterflies indirectly by reducing host plant presence or quality [24,31]. Understanding the link between water availability and population response is then the key to making informed management decisions about recovery goals and long-term conservation plans for rare species.

In this paper, we show how water availability from stream discharge influences the population size of a U.S. federally endangered butterfly, the St. Francis' satyr (Neonympha mitchellii francisci). The St. Francis' satyr inhabits ephemeral wetlands and is restricted entirely to Fort Bragg Military Installation in central North Carolina [32]. The population size of the St. Francis's satyr has declined dramatically in the past decade [33]; however, recent restoration work within local wetlands has shown promise for supporting large populations again [34]. The host plants for adult St. Francis' satyrs are wetland-dependent, and therefore directly impacted by consistent water availability from local streams. Linking water availability to population response appears key to understanding how factors such as climate and human presence in the landscape may affect recovery goals for the species.

\section{Materials and Methods}

The St. Francis' satyr is a U.S. federally listed endangered butterfly that is a subspecies of Neonympha mitchellii [32]. The current population is estimated to consist of only a few thousand individuals [33]. Extensive searching has determined that the St. Francis' satyr is severely restricted in its range and occurs only within about 10 ha of land on Fort Bragg Military Installation, located in central North Carolina. Populations are found on Fort Bragg both within and outside of artillery impact areas; due to military restrictions, only populations outside of artillery impact areas can be regularly monitored. The St. Francis' satyr is found exclusively in ephemeral wetlands that are created by flooding from beavers and maintained by infrequent small fires that retard woody growth. Individuals are capable of short dispersal along streams and depend on a closely spaced network of wetlands in order to persist once individual sites dry out. Host plants for the St. Francis' satyr are wetland sedges in the Carex family, particularly Carex mitchelliana [32].

The disturbance-dependent nature of the ecosystem makes it particularly challenging to manage [34], and exacerbates the sensitivity of St. Francis' satyrs to the potential effects of climate change. St. Francis' satyr phenology is known to be sensitive to heat accumulation in the environment [32,35], and precipitation levels influence water levels in the streams and creeks where St. Francis' satyrs are found. The two most dominant factors in creating a high quality habitat - the presence of beavers and the absence of woody encroachment-are both influenced by human modification of the landscape [33]. Since 2011, active restoration of wetland habitats in close proximity to known occupied sites outside of artillery impact areas has been ongoing, with expected dispersal between restored and non-restored sites. Restoration actions include inundation of sites with artificial dams as well as hardwood removal from the canopy (for full description see Reference [34]). 
Six St. Francis' satyr subpopulations from sites with no restoration were surveyed outside of artillery impact areas from 2003-2017 using modified Pollard-Yates counts [36,37]. Daily surveys were conducted along standard transects each summer during the second flight period, from mid-July to mid-August. For each subpopulation, we calculated a Pollard-Yates (PY) index [38], which is a standard index of population size and is highly correlated with mark-recapture estimates of population size [37]. We estimated subpopulation size based on the PY index by using an equation modified from Reference [32]. Data from each subpopulation were then aggregated to form an estimate of the total population size for the species outside of artillery impact areas. Surveys were not conducted at known populations within artillery impact areas due to heavy restrictions on access. We chose to focus on population size rather than population growth rate, as unusually small estimates in recent years were more likely to disproportionately affect calculations of lambda.

We conducted vegetation surveys in 2006 and from 2009-2012 during at least two years at five of the six subpopulations where $C$. mitchelliana was present. Within each site we randomly placed one to seven (an average of five) $3 \mathrm{~m} \times 8 \mathrm{~m}$ plots adjacent to butterfly survey transects and calculated the percent cover of $C$. mitchelliana [39]. Not all plots were surveyed at each site in each year.

We obtained mean daily discharge data from 1970-2017 from a USGS stream monitoring station at Flat Creek, NC (USGS, 2016). Flat Creek supported St. Francis' satyr populations at the start of our study until 2009 and is in close proximity to streams where many St. Francis' satyr populations are currently found. Flat Creek provides a strong representative sample of water flow for the numerous creeks that are found on Fort Bragg. We calculated the average water flow per water year (1 October-30 September) and conducted a linear regression to determine if water flow significantly changed across years.

To assess the impact of water availability on butterfly and host plant populations, we conducted a linear mixed effects regression using the site as a fixed effect. Since data for both the PY index and percentage of $C$. mitchelliana were right-skewed, we log transformed values for PY index and logit transformed values for percentage of $C$. mitchelliana [40]. We conducted models for both the PY index and amount of $C$. mitchelliana using water, year, and their interaction as random effects, with year being the repeated measures variable. Because there can be a lag time in species' response to environmental conditions [41], we conducted the analysis with water flow in the same year ( $t)$ as butterfly and host plant surveys, and also with water flow in the year prior $(\mathrm{t}-1)$ to butterfly and host plant surveys. We also modelled the direct relationship between the PY index and amount of $C$. mitchelliana. The PY index values of zero were eliminated from the analysis the year following population extinction at a site, as water availability was no longer influential in St. Francis' satyr population size once no butterflies were present.

\section{Results}

The total St. Francis' satyr population size outside artillery ranges was estimated to be 530 individuals in the second flight period of 2003, the first year that population size was quantified (Figure 1). The population increased to a maximum of 1730 individuals in 2004 before dropping to 25 individuals in 2016 and only a few individuals in 2017. However, once individuals from restored sites are included, the population estimate for 2017 was 560 individuals, with a peak of 790 individuals seen in 2016. Estimates do not include individuals in artillery impact areas, where thousands of individuals may persist.

Average water flow per year at Flat Creek significantly decreased by $0.11 \mathrm{~m}^{3} / \mathrm{s}$, or $29 \%$, from 1970-2017 (slope $=-0.002, p=0.004$, Figure 2a). Average water flow ranged from a low of $0.14 \mathrm{~m}^{3} / \mathrm{s}$ in 2002 to a high of $0.57 \mathrm{~m}^{3} / \mathrm{s}$ in 1973 (mean $=0.32$, s.d. $=0.08$ ).

The average percentage of $C$. mitchelliana at a site ranged from $0.25 \%$ to $12.43 \%$ (mean $=3.61$, s.d. = 3.35). The amount of C. mitchelliana significantly increased with water flow of the previous water year (slope $=-2.307, p=0.02$, Figure $2 b$ ). The PY index ranged from 0 to 67 (mean $=10.0$, s.d. $=11.8$ ). The PY index was not significantly influenced by water flow of the previous water year (slope $=3.112$, 
$p=0.91$, Figure 2c). The water flow of the current year did not significantly influence the amount of $C$. mitchelliana $(p=0.24)$ or the PY index $(p=0.48)$. The year was significantly correlated with the PY index for both the current water year $(p<0.001)$ and the previous water year $(p<0.001)$. Higher amounts of C. mitchelliana were associated with higher PY index values (slope $=0.037, p=0.32$, Figure 2d).

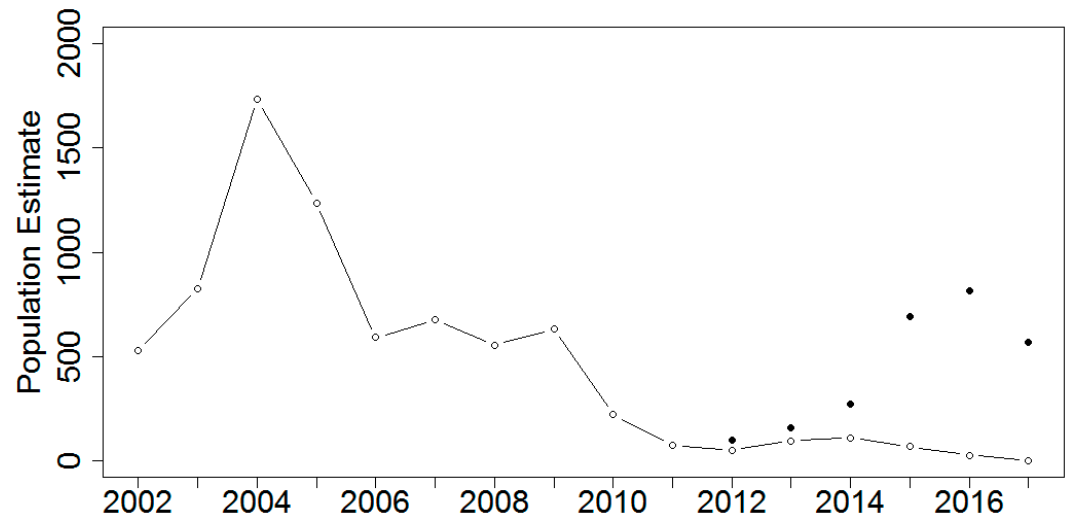

Figure 1. Estimated population size of St. Francis' satyrs during the second flight period from 2003-2017 outside of artillery impact areas on Fort Bragg, NC. Closed circles represent population size when restored sites were included.
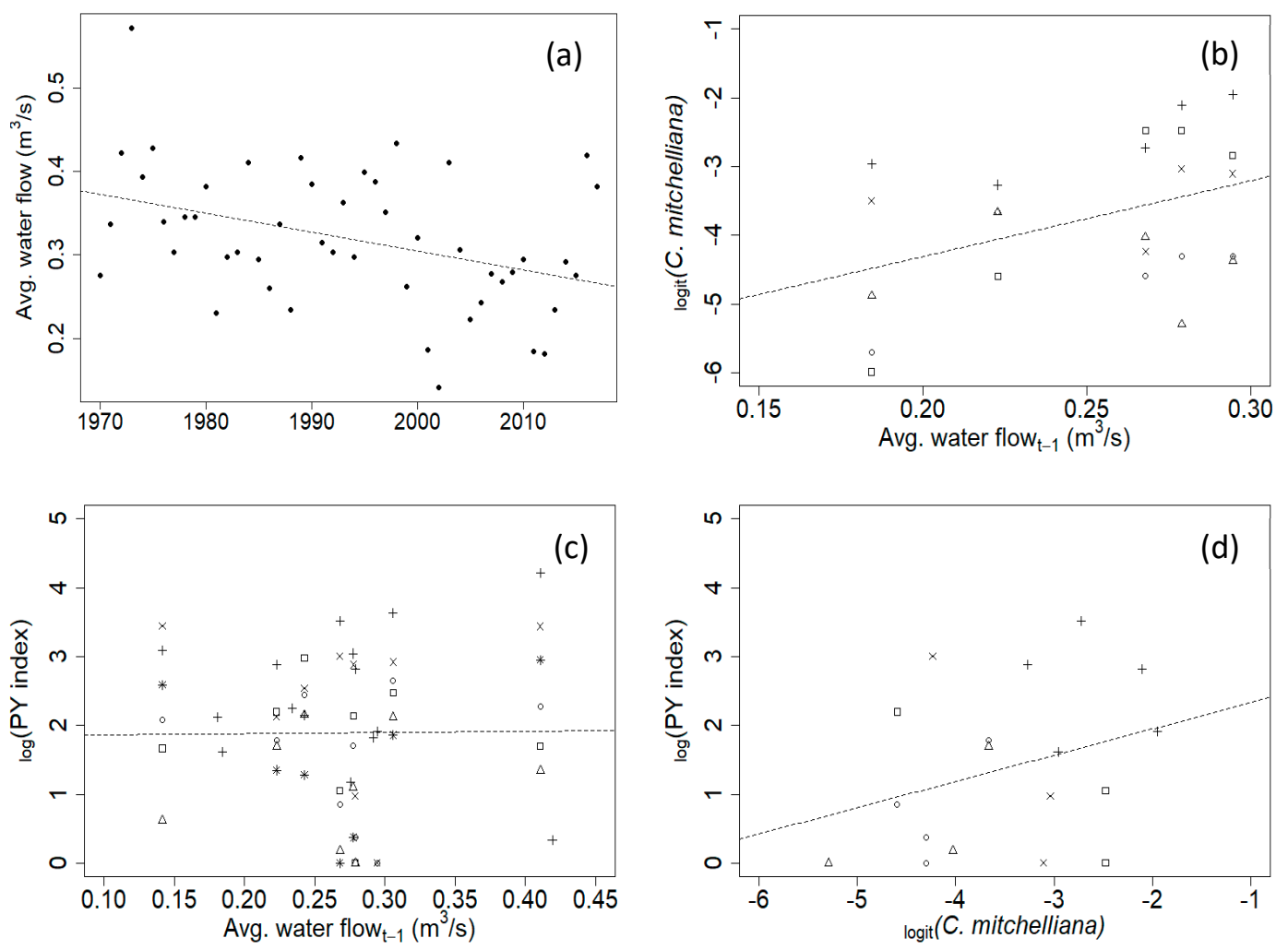

Figure 2. Effects of water availability on plants and butterflies. (a) Change in average annual water flow from 1970-2017. (b) Average amount of C. mitchelliana present based on average annual water flow of previous water year. (c) Pollard-Yates (PY) index of St. Francis' satyrs based on average annual water flow of previous water year. (d) Relationship between amount of C. mitchelliana and PY index of St. Francis' satyrs. Different symbols represent an individual site where butterfly or plant surveys were conducted. 


\section{Discussion}

We have shown the direct link by which water availability influenced the amount of host plant present for a rare butterfly species. Water availability in the Fort Bragg region has significantly declined for several decades (Figure 2a), leading to lower amounts of $C$. mitchelliana in key wetland habitats (Figure 2b). These altered environmental conditions have resulted in a large decrease in the population size of St. Francis' satyr. Only after active restoration of wetland habitats have we observed a population increase (Figure 1). Population levels at sites outside of artillery impact areas have dropped from a historic high of nearly 2000 individuals in 2004 to current estimates of less than 110 individuals each year since 2011, a decline of $95 \%$. Five of the six subpopulations surveyed since 2003 have been extirpated due to low water levels in streams, including both populations that were found on Flat Creek, the stream from which we collected our water data. This downward trend is compounded by small-scale factors such as woody encroachment and beaver eradication that alter hydrology within occupied sites. These changes can interact with large-scale, long-term changes, such as climate and human activities, that will continue to influence St. Francis' satyrs in the future. Ongoing conservation efforts must consider the potentially devastating impact that the combination of small-scale and large-scale mechanisms may have on species recovery goals.

Although the population size of St. Francis' satyr is not directly impacted by water flow (Figure 2c), there was a direct correlation between butterfly persistence and the presence of its host plant (Figure 2d). In 2011, we began active restoration along two creek drainages that support St. Francis' satyr populations, with a focus on altering water conditions by mimicking the favorable environment created by beavers. We combined artificial dam creation, which increased standing water to levels preferred by Carex sedges, with widespread hardwood removal, which eliminated encroaching trees and shrubs and decreased evapotranspiration rates [34]. The resulting increases in water availability directly contributed to significant increases in amount of $C$. mitchelliana in restored sites [34,42]. Consequently, populations of St. Francis' satyr in restored sites have increased dramatically from 50 individuals in 2012 to a population of almost 800 by 2016 (Figure 1).

The implications of linking water availability to population declines extend beyond St. Francis' satyrs. Other butterfly species that inhabit wetlands or riparian zones, or with host plants that require saturated soils, may show a similar dependence on water availability that trumps environmental conditions such as vegetation structure or composition [24,31]. In addition to butterflies, altered water availability has also been linked to population declines for amphibians [43,44], birds [45,46], and mammals [47,48]. The link between water and population size could be extended to numerous plant and invertebrate species, which are often used as indicators for the status of rivers, streams, and wetlands due to their sensitivity to water conditions.

The underlying causes of lowered water availability for St. Francis' satyr are unknown, but potentially have their origin in the synergistic effects of human activities and climate [1,49]. The human population of Cumberland County, which includes most of Fort Bragg and the adjacent city of Fayetteville, increased by $24 \%$ from 1985 to 2015 [50], and public water withdrawals in the county increased by 70\% from 1985 to 2010 [51]. In addition, mean annual temperature at Fort Bragg has significantly increased since 1960, and total annual precipitation has decreased in the same time period [52]. When considered simultaneously, these factors can have a large, synergistic effect on population response [53], and ultimately may elicit a broad response seen from the genetic level up to the ecosystem level [4]. Additional factors outside the scope of climatic and anthropogenic influences may contribute to reduced water flow, such as changes in landscape topography or shifts in species composition within stream networks. Studies that more closely evaluate sources of water reduction could help clarify the mechanism by which water availability is altered.

We have shown how water availability plays a critical role in mediating host plant growth and thus contributes to population declines for St. Francis' satyr. Future management actions aimed at achieving species recovery goals must consider how water availability is likely to change in the future and whether conservation plans are adequate to mitigate any potential negative effects. Short term 
planning should focus on maintaining access for beavers along wetland corridors that are in close proximity to St. Francis' satyrs, and on preventing the encroachment of woody shrubs and trees into occupied sites. Over the long term, it is currently unknown whether temperature or precipitation is ultimately more influential in determining how populations will respond, since the extent to which precipitation cycles will be altered by climate change is still uncertain [54]. Only when we fully understand the pathway by which threatened and endangered populations are influenced can we make effective conservation and management plans to ensure species persistence under climate change.

Author Contributions: Both authors contributed equally to conceiving the study, collecting and interpreting data, and developing the final manuscript. H.L.C. conducted the analysis and drafted the manuscript.

Funding: This research was funded by the Fort Bragg Army Installation.

Acknowledgments: We would like to thank P. Hamel for early discussions on this topic, as well as the numerous technicians who have conducted butterfly and vegetation surveys. We thank S. Diamond, T. Wepprich, P. Hamel, and three anonymous reviewers for providing comments on an earlier version of this manuscript.

Conflicts of Interest: The authors declare no conflict of interest. The funder had no role in the design of the study; in the collection, analyses, or interpretation of data; in the writing of the manuscript, and in the decision to publish the results.

\section{References}

1. Dirzo, R.; Young, H.S.; Galetti, M.; Ceballos, G.; Isaac, N.J.B.; Collen, B. Defaunation in the Anthropocene. Science 2014, 345, 401-406. [CrossRef] [PubMed]

2. Urban, M.C. Accelerating extinction risk from climate change. Science 2015, 348, 571-573. [CrossRef] [PubMed]

3. Urban, M.C.; Bocedi, G.; Hendry, A.P.; Mihoub, J.-B.; Pe'er, G.; Singer, A.; Bridle, J.R.; Crozier, L.G.; Meester, L.D.; Godsoe, W.; et al. Improving the forecast for biodiversity under climate change. Science 2016, 353, aad8466. [CrossRef] [PubMed]

4. Scheffers, B.R.; Meester, L.D.; Bridge, T.C.L.; Hoffmann, A.A.; Pandolfi, J.M.; Corlett, R.T.; Butchart, S.H.M.; Pearce-Kelly, P.; Kovacs, K.M.; Dudgeon, D.; et al. The broad footprint of climate change from genes to biomes to people. Science 2016, 354, aaf7671. [CrossRef] [PubMed]

5. Fischer, J.; Lindenmayer, D.B. Landscape modification and habitat fragmentation: A synthesis. Glob. Ecol. Biogeogr. 2007, 16, 265-280. [CrossRef]

6. Schuetz, J.G.; Langham, G.M.; Soykan, C.U.; Wilsey, C.B.; Auer, T.; Sanchez, C.C. Making spatial prioritizations robust to climate change uncertainties: A case study with North American birds. Ecol. Appl. 2015, 25, 1819-1831. [CrossRef] [PubMed]

7. Ockendon, N.; Baker, D.J.; Carr, J.A.; White, E.C.; Almond, R.E.A.; Amano, T.; Bertram, E.; Bradbury, R.B.; Bradley, C.; Butchart, S.H.M.; et al. Mechanisms underpinning climatic impacts on natural populations: Altered species interactions are more important than direct effects. Glob. Chang. Biol. 2014, 20, 2221-2229. [CrossRef] [PubMed]

8. Traill, L.W.; Lim, M.L.M.; Sodhi, N.S.; Bradshaw, C.J.A. Mechanisms driving change: Altered species interactions and ecosystem function through global warming. J. Anim. Ecol. 2010, 79, 937-947. [CrossRef] [PubMed]

9. Cahill, A.E.; Aiello-Lammens, M.E.; Fisher-Reid, M.C.; Hua, X.; Karanewsky, C.J.; Ryu, H.Y.; Sbeglia, G.C.; Spagnolo, F.; Waldron, J.B.; Warsi, O.; et al. How does climate change cause extinction? Proc. R. Soc. B Biol. Sci. 2013, 280. [CrossRef] [PubMed]

10. Barnett, T.P.; Pierce, D.W.; Hidalgo, H.G.; Bonfils, C.; Santer, B.D.; Das, T.; Bala, G.; Wood, A.W.; Nozawa, T.; Mirin, A.A.; et al. Human-Induced Changes in the Hydrology of the Western United States. Science 2008, 319, 1080-1083. [CrossRef] [PubMed]

11. Schindler, D.W.; Donahue, W.F. An impending water crisis in Canada's western prairie provinces. Proc. Natl. Acad. Sci. USA 2006, 103, 7210-7216. [CrossRef] [PubMed]

12. Weiss, S.B.; Murphy, D.D.; White, R.R. Sun, Slope, and Butterflies: Topographic Determinants of Habitat Quality for Euphydryas Editha. Ecology 1988, 69, 1486-1496. [CrossRef] 
13. Henry, E.H.; Haddad, N.M.; Wilson, J.; Hughes, P.; Gardner, B. Point-count methods to monitor butterfly populations when traditional methods fail: A case study with Miami blue butterfly. J. Insect Conserv. 2015, 19, 519-529. [CrossRef]

14. Haddeland, I.; Heinke, J.; Biemans, H.; Eisner, S.; Flörke, M.; Hanasaki, N.; Konzmann, M.; Ludwig, F.; Masaki, Y.; Schewe, J.; et al. Global water resources affected by human interventions and climate change. Proc. Natl. Acad. Sci. USA 2014, 111, 3251-3256. [CrossRef] [PubMed]

15. Nagy, R.C.; Porder, S.; Neill, C.; Brando, P.; Quintino, R.M.; do Nascimento, S.A. Structure and composition of altered riparian forests in an agricultural Amazonian landscape. Ecol. Appl. 2015, 25, 1725-1738. [CrossRef] [PubMed]

16. Greet, J.; Cousens, R.D.; Webb, J.A. Flow regulation affects temporal patterns of riverine plant seed dispersal: Potential implications for plant recruitment. Freshw. Biol. 2012, 57, 2568-2579. [CrossRef]

17. Johnson, S.N.; Staley, J.T.; McLeod, F.A.L.; Hartley, S.E. Plant-mediated effects of soil invertebrates and summer drought on above-ground multitrophic interactions. J. Ecol. 2011, 99, 57-65. [CrossRef]

18. Jamieson, M.A.; Trowbridge, A.M.; Raffa, K.F.; Lindroth, R.L. Consequences of Climate Warming and Altered Precipitation Patterns for Plant-Insect and Multitrophic Interactions. Plant. Physiol. 2012, 160, 1719-1727. [CrossRef] [PubMed]

19. Diamond, S.E.; Cayton, H.; Wepprich, T.; Jenkins, C.N.; Dunn, R.R.; Haddad, N.M.; Ries, L. Unexpected phenological responses of butterflies to the interaction of urbanization and geographic temperature. Ecology 2014, 95, 2613-2621. [CrossRef]

20. Oliver, T.H.; Marshall, H.H.; Morecroft, M.D.; Brereton, T.; Prudhomme, C.; Huntingford, C. Interacting effects of climate change and habitat fragmentation on drought-sensitive butterflies. Nat. Clim. Chang. 2015, 5, 941-945. [CrossRef]

21. Fox, R. The decline of moths in Great Britain: A review of possible causes. Insect Conserv. Divers. 2013, 6, 5-19. [CrossRef]

22. McLaughlin, J.F.; Hellmann, J.J.; Boggs, C.L.; Ehrlich, P.R. Climate change hastens population extinctions. Proc. Natl. Acad. Sci. USA 2002, 99, 6070-6074. [CrossRef] [PubMed]

23. Wallisdevries, M.F.; Van Swaay, C.A.M. Global warming and excess nitrogen may induce butterfly decline by microclimatic cooling. Glob. Chang. Biol. 2006, 12, 1620-1626. [CrossRef]

24. Ehrlich, P.R.; Murphy, D.D.; Singer, M.C.; Sherwood, C.B.; White, R.R.; Brown, I.L. Extinction, reduction, stability and increase: The responses of checkerspot butterfly (Euphydryas) populations to the California drought. Oecologia 1980, 46, 101-105. [CrossRef] [PubMed]

25. Thomas, C.D.; Cameron, A.; Green, R.E.; Bakkenes, M.; Beaumont, L.J.; Collingham, Y.C.; Erasmus, B.F.N.; de Siqueira, M.F.; Grainger, A.; Hannah, L.; et al. Extinction risk from climate change. Nature 2004, 427, 145-148. [CrossRef] [PubMed]

26. Schwartz, M.W.; Iverson, L.R.; Prasad, A.M.; Matthews, S.N.; O'Connor, R.J. Predicting Extinctions as a Result of Climate Change. Ecology 2006, 87, 1611-1615. [CrossRef]

27. Severns, P.M.; Boldt, L.; Villegas, S. Conserving a wetland butterfly: Quantifying early lifestage survival through seasonal flooding, adult nectar, and habitat preference. J. Insect Conserv. 2006, 10, 361. [CrossRef]

28. Joy, J.; Pullin, A.S. The effects of flooding on the survival and behaviour of overwintering large heath butterfly Coenonympha tullia larvae. Biol. Conserv. 1997, 82, 61-66. [CrossRef]

29. Webb, M.R.; Pullin, A.S. Effects of submergence by winter floods on diapausing caterpillars of a wetland butterfly, Lycaena dispar batavus. Ecol. Entomol. 1998, 23, 96-99. [CrossRef]

30. Fies, R.; Rabl, D.; Schulze, C.H.; Fiedler, K. Summer floods shape meadow butterfly communities in a floodplain nature reserve in Central Europe. J. Insect Conserv. 2016, 20, 433-445. [CrossRef]

31. Drahovzal, S.A.; Loftin, C.S.; Rhymer, J. Environmental predictors of shrubby cinquefoil (Dasiphora fruticose) habitat and quality as host for Maine's endangered Clayton's copper butterfly (Lycaena dorcas claytoni). Wetl. Ecol. Manag. 2015, 23, 891-908. [CrossRef]

32. Kuefler, D.; Haddad, N.M.; Hall, S.; Hudgens, B.; Bartel, B.; Hoffman, E. Distribution, population structure and habitat use of the endangered Saint Francis Satyr butterfly, Neonympha mitchellii francisci. Am. Midl. Nat. 2008, 159, 298-320. [CrossRef]

33. Cayton, H.; Henry, E.; Kiekebusch, E.; Haddad, N. Research for the Conservation and Restoration of an Endangered Butterfly, the St. Francis' Satyr; Report Submitted to Fort Bragg Army Installation; Fort Bragg Army Installation: Ft. Bragg, NC, USA, 2016. 
34. Cayton, H.; Haddad, N.M.; Ball, B.; Henry, E.; Aschehoug, E. Habitat Restoration as a Recovery Tool for a Disturbance-Dependent Butterfly, The Endangered St. Francis' Satyr. In Butterfly Conservation in North America; Daniels, J.C., Ed.; Springer: Heidelberg, Germany, 2015; pp. 147-159. ISBN 978-94-017-9851-8.

35. Cayton, H.L.; Haddad, N.M.; Gross, K.; Diamond, S.E.; Ries, L. Do growing degree days predict phenology across butterfly species? Ecology 2015, 96, 1473-1479. [CrossRef]

36. Pollard, E. A method for assessing changes in the abundance of butterflies. Biol. Conserv. 1977, 12, 115-134. [CrossRef]

37. Haddad, N.M.; Hudgens, B.; Damiani, C.; Gross, K.; Kuefler, D.; Pollock, K. Determining Optimal Population Monitoring for Rare Butterflies. Conserv. Biol. 2008, 22, 929-940. [CrossRef] [PubMed]

38. Pollard, E.; Yates, T.J. Monitoring Butterflies for Ecology and Conservation; Springer: Heidelberg, Germany, 1994; ISBN 978-0-412-63460-4.

39. Bartel, R.A.; Haddad, N.M.; Wright, J.P. Ecosystem engineers maintain a rare species of butterfly and increase plant diversity. Oikos 2010, 119, 883-890. [CrossRef]

40. Warton, D.I.; Hui, F.K.C. The arcsine is asinine: The analysis of proportions in ecology. Ecology 2011, 92, 3-10. [CrossRef] [PubMed]

41. Wu, D.; Zhao, X.; Liang, S.; Zhou, T.; Huang, K.; Tang, B.; Zhao, W. Time-lag effects of global vegetation responses to climate change. Glob. Chang. Biol. 2015, 21, 3520-3531. [CrossRef] [PubMed]

42. Aschehoug, E.T.; Sivakoff, F.S.; Cayton, H.L.; Morris, W.F.; Haddad, N.M. Habitat restoration affects immature stages of a wetland butterfly through indirect effects on predation. Ecology 2015, 96, 1761-1767. [CrossRef] [PubMed]

43. Kiesecker, J.M.; Blaustein, A.R.; Belden, L.K. Complex causes of amphibian population declines. Nature 2001, 410, 681-684. [CrossRef] [PubMed]

44. McMenamin, S.K.; Hadly, E.A.; Wright, C.K. Climatic change and wetland desiccation cause amphibian decline in Yellowstone National Park. Proc. Natl. Acad. Sci. USA 2008, 105, 16988-16993. [CrossRef] [PubMed]

45. Sanderson, F.J.; Donald, P.F.; Pain, D.J.; Burfield, I.J.; van Bommel, F.P.J. Long-term population declines in Afro-Palearctic migrant birds. Biol. Conserv. 2006, 131, 93-105. [CrossRef]

46. Quesnelle, P.E.; Fahrig, L.; Lindsay, K.E. Effects of habitat loss, habitat configuration and matrix composition on declining wetland species. Biol. Conserv. 2013, 160, 200-208. [CrossRef]

47. Ogutu, J.O.; Owen-Smith, N. ENSO, rainfall and temperature influences on extreme population declines among African savanna ungulates. Ecol. Lett. 2003, 6, 412-419. [CrossRef]

48. Adams, R.A.; Hayes, M.A. Water availability and successful lactation by bats as related to climate change in arid regions of western North America. J. Anim. Ecol. 2008, 77, 1115-1121. [CrossRef] [PubMed]

49. Brook, B.W.; Sodhi, N.S.; Bradshaw, C.J.A. Synergies among extinction drivers under global change. Trends Ecol. Evol. 2008, 23, 453-460. [CrossRef] [PubMed]

50. United States Census Bureau. 2017. Available online: https://www.census.gov/en.html (accessed on 19 July 2016).

51. USGS National Water Information System. 2017. Available online: https://waterdata.usgs.gov/nwis (accessed on 22 July 2016).

52. NOAA National Centers for Environmental Information (NCEI). 2017. Available online: https://www.ncdc. noaa.gov/ (accessed on 30 April 2018).

53. Stefanescu, C.; Carnicer, J.; Peñuelas, J. Determinants of species richness in generalist and specialist Mediterranean butterflies: The negative synergistic forces of climate and habitat change. Ecography 2011, 34, 353-363. [CrossRef]

54. IPCC. IPCC Working Group I Contribtuion to the the IPCC Fifth Assessment Report-Climate Change 2013: The Physical Science Basis; IPCC: Geneva, Switzerland, 2013; p. 207.

(C) 2018 by the authors. Licensee MDPI, Basel, Switzerland. This article is an open access article distributed under the terms and conditions of the Creative Commons Attribution (CC BY) license (http:/ / creativecommons.org/licenses/by/4.0/). 